\title{
8 West-German - Chinese Trade Experiences in Historical Perspective
}

Nearly 30 years on from its first formulation, the contact zone paradigm is still being debated and refined as its first formulator, Mary Louise Pratt, dialogues with her most constructive critics. Though originally proposed as a research tool in the field of literacy and literary theories, it has proved versatile, thought-provoking and generally popular in many other walks of the humanities, and indeed wherever the notion of "culture" is amenable to problemanalysis (Hong 2001, 259-83; Giffard 2016, 29-41). Without any claim to exhaustiveness in what is potentially an infinite topic, my chapter sets out to assess the contact zone paradigm in a field where it has not yet been seriously applied: economic history in its broadest sense. I will attempt this by means of a case study that dates back to the post-colonial era, but which I will try to frame in a longer-term analysis: the negotiations between the Federal Republic of Germany and the People's Republic of China in the years following 1949, their aim being to promote and regulate trade between the two countries, despite the geopolitical impediments and the unfavourable ideological climate caused by the Cold War.

\section{Contact Zones and Economic History}

Although recent economic research seems intent chiefly on defining and quantifying the negative effect of cultural factors on economic exchange, viewing them as mere "biases" or "barriers" (Guiso, Sapienza and Zingales 2004, 1-25; Kónya 2006, 494-507), many other disciplines agree that conflict and cultural contamination have always been an intrinsic component of economic action (Spillman 2006, 1047-71). Since prehistoric times that component has affected much more than the purely material side to the exchange of goods and services; it has played a powerful part in producing social meanings and relations within the societies

\footnotetext{
Note: This research has been funded by the Italian Ministry of Education as part of the National Research Project (PRIN 2017-2020) "Percorsi di avvicinamento fra Europa Occidentale e Repubblica Popolare Cinese negli anni della Guerra Fredda: Italia e Repubblica Federale Tedesca a confronto, 1949-1972" (The rapprochement between Western Europe and the People's Republic of China during the Cold War: A comparison between Italy and West Germany 1949-1972")

Ә Open Access. (C) 2020 Giovanni Bernardini, published by De Gruyter. (cc) BY-NC-ND This work is licensed under a Creative Commons Attribution-NonCommercial-NoDerivatives 4.0 International License.

https://doi.org/10.1515/9783110663426-009
} 
involved. The contact zone paradigm seems highly suited to identifying certain cultural factors at play in economic exchange. In the first place, it counters the stereotype of communities closed within their own process of self-definition, opposed to which it focuses on the relational side, which distinguishes and affects every stage of their development. ${ }^{1}$ Contact zones are places of comparison and negotiation, factors that have been typical parameters of economic exchange from the era of barter down to present-day e-commerce. If one accepts the anthropological definition of "culture" to include a human group's typical material, and not just social or spiritual, manifestations, one comes to see the material need for economic exchange among social groups as one of the contact-shaping forces, found at all periods and latitudes, that have opened and still open the door to comparison and cultural contamination. Although historians often consider such a knock-on effect involuntary and unpredictable in its consequences, it is equally true to say that the gradual emergence of social professionals in charge of economic exchange has often endowed them with sensitivity to the cultural factors involved: whether it be in facilitating new contact, or channelling it along previously established routes, or even restricting it to the minimum degree possible. Again, as economic activities have grown specialised and refined, greater weight has attached to expertise and the technical language needed in economic exchanges, a proper lingua franca making for prompter understanding among people handling economic contacts.

Another basic feature of the contact zone paradigm makes it peculiarly suitable for historical investigation of economic exchanges: the space factor. The physical space in which cultures meet and clash immediately leads us to the places designed for economic exchange among geographically and historically separated human communities, symbolised by that universal and traditional phenomenon, the market (Hahn 2018, 1-19). Market systems involving precise locations, codified roles and customs, and periodic recurrence, have long been recognized "as key factors in the development and integration of many complex societies", regardless of their geographical or historical distance (Minc 2006, 82-3). The model continues to this day in far from symbolic form via international trade-fairs. Yet recent centuries have tried to make the contact zone model less spontaneous, less episodic and more institutionalized and regulated, and this has greatly affected economic relations between separate human communities. The reasons for this change lie in the global extent of such transactions, as well as the increasing complexity and bureaucracy prevailing in the societies involved. In particular, the age of empires and

1 For this and other references to Mary Louise Pratt's formulation, the reader is referred to the introduction to the present volume. 
colonies introduced an economic space dimension that was heavily conditioned by power dynamics between dominant and subordinate parties, centre and periphery, as well as by the idea of extraterritorial status. All this established an insurmountable hierarchy among the actors in play, including the right to limit or even deny subordinates all access or contact. However, studies on specific cases over the years have shown that deliberate and objective obstacles failed to prevent spatial proximity from generating distinct contact zones which had a lasting effect on all the communities involved, extending well beyond the immediately concerned territories (Larrier 2004, 96-107; Raj 2011, 55-82).

\section{"The Face of the West": Germany's Economic Presence in China}

For many reasons which it is here impossible to enlarge on, China remained for centuries a land of experiment and consolidation for special foreign (mainly western) enclaves. Economic reasons were by no means the only driving force behind the process, but they did play a predominant role (Feuerwerker 1983, 192-93; Nield 2015, ix-xi). The 19th century saw the rise of that peculiar model, the "concession": a space that the imperial authorities "conceded" to western powers within built-up areas. Although based on the strict legal principle of extraterritoriality and separation from the local population, the concessions became a place from which foreign influence radiated across the surrounding territory and even permanently altered China's political, economic, social and urban profile. The peculiar condition obtaining in some of these territories, where concessions included as many as nine different foreign powers in one and the same area, eventually made them something quite different from mere colonies. "Hyper-colonies", say some, Foucaultian "heterotopias" claim others: be that as it may, the concessions were places where inequality of power relations did not prevent "the intersection and juxtaposition of practices and representations" among foreign powers or between them and the native population (Marinelli 2009, 399-405). The concessions experience had a decisive influence on SinoGerman relations, albeit for unimaginable reasons. First, Germany made her economic and cultural presence felt in China somewhat later than other imperial powers. This was no doubt due to the fact that German unification only occurred in 1871, so that her governing authorities had difficulty in muscling in on the French and above all the British in China. As a result, German non-state actors initially enjoyed less governmental protection than their competitors - a fact which actually prompted them to experiment more freely with original and 
flexible strategies for penetrating Chinese society (Leutner and Mühlhahn 2001, 9-14). In the economic field their efforts were crowned with marked success, coinciding as they did with the phase of history (the last quarter of the 19th century) when Germany took the lead in the so-called Second Industrial Revolution. This meant that German firms' production of avantgarde goods and services was matched by a widespread desire for modernization on the part of the Chinese elites. This gave rise to flexible, scheduled, locally circumscribed contact zones and to a limited number of interlocutors chosen by either side. Such zones proliferated in the large cities and around the German companies' commercial and representative offices, the number of which went from 7 in 1855 to 122 in 1901 (Kirby 1984, 11-15). On a material plane such results gave German economic and technological power a broad and lasting influence in Chinese culture of the time, illustrated by pioneering achievements like construction of the first electric tramway in Beijing in 1899, the first high-voltage power line in the country, massive exports of military equipment and also of common daily objects such as telephones, pointer telegraphs, water meters and synthetic dyes for textiles. All this certainly met with approval by the German government though it couched this in terms less threatening to Chinese sovereignty than were adopted by the main European competitors.

The trend was to change quite substantially at the turn of the century when Germany's political authorities decided to emulate the other European powers by formally taking possession of extra-European areas to add to their Empire (Berghahn 1996, 5). In China, this took the form of obtaining concessions from the imperial power at Hankou, Tianjin and in the Kiautschou Bay, by coercion or political pretext (chiefly connected with suppressing the Boxer Rebellion). In this, Germany lagged decades behind France, Great Britain and the United States. Despite the overt objective of combining territorial with economic penetration, there was much talk in the German economic world even at the time about not increasing German influence in China by "cannons" but by cultural means, promoting the image of the Reich as an example of a modern power that posed no threat to Chinese sovereignty (Machetzki 1991, 401-408). As it was, the Chinese reaction to Berlin's imperial and territorial new turn was to cool the official welcome even to the German economic presence. The situation would worsen further in 1912 when the leaders of the newborn Republic showed marked intolerance to the concessions system and to the political and military presence of westerners (Tanner 2010, 133). The German experience of concessions was anyway short-lived since Germany forfeited control of them upon losing the First World War. Surprisingly, that setback proved no impediment but a competitive advantage in the medium term. The fledgling Weimar Republic's interest in China's market and resources, and the latter's interest in German's 
economic and technological potential (remaining roughly intact despite the defeat) were too great to be ignored by the two sides. What is more, restrictions imposed to Germany by the Versailles Treaty on any new extra-European expansion enabled China for the first time to base relations with a European country "upon both the principle and practice of equality and mutual benefit" (Kirby 1997, 443-44). The relationship between the two countries was quick to recover and overtake the pre-war position. Many comparative analyses see that relationship as "the most successful of the Republican period," raising China "into the very centre of global power politics." The inadmissibility of any active support by the German state prevented their forming a "business system" based on "triple integration through the market, through imperial politics and through the articulation of interests" despite which German trade with China prospered from the mid-1920s on (Osterhammel 1986, 302). This was no doubt due to the "versatility of Chinese diplomacy in pursuing broadly consistent goals through an extraordinarily diverse set of relationships within a short span of years"; but also to the ingenuity shown by German companies and consortiums in going in for "informal arrangements with the Chinese on local, provincial and even central government level," rather than formal treaties of the traditional kind. The strategy at the time largely involved sending military and economic "advisers" to China, often with the backing of the public power but above all endowed with the flexibility of the private sector (Martin 1981). In bilateral Sino-German relations the model of contact zone that began to prevail was less linked to any stable, lasting physical presence, or coercion and inequality of power relations, and based more on equality: a virtual, flexible model depending on personal skill and technique, and on the experience of the mediators involved. As a result, by the mid-Thirties China had become Germany's third commercial partner and the third recipient of German direct investments abroad, thanks to the involvement of the country's leading firms. The consequences of this trend were not confined to the economic sphere: thanks to her industrial, technological and commercial potential, once more Germany became again a source of inspiration to those wishing to modernize China. That inspiration continued even when the Nazi regime came to power: some of the Guomindang were attracted by its ability to combine social conservatism with an industrial and technological spirit of modernization - something they wished to emulate in republican China. One may thus safely maintain that the pattern of material exchange forming between the two countries, favoured by the German state's need to toe a discreet line devoid of any classic imperialistic designs, made German culturally and ideologically the main foreign influence in China from the mid-Twenties on, such as to become "the face of the West in China during the 'Nanjing decade' (1927-1937)" (Kirby 1984, 20). Politics 
eventually queered the pitch from 1937 when the Hitler regime chose to prioritise relations with Japan which was now openly at war with China. The Berlin authorities gradually withdrew all advisers, broke off collaboration over munitions and eventually sought to re-route economic interests towards the Manzhouguo puppet state. The German economic world put up some resistance, as objective operating conditions enabled it to do, trusting that the experience gained in previous decades would make the Chinese market potential more attractive than other alternatives (Leitz 2004, 130). Thus, economic cooperation was never completely interrupted between the German private sector and the Chinese nationalist government, at least until the 1941 declaration of war.

\section{After 1949: Shielding Trade from the "Cold War"}

The new World War and its aftermath hampered the resumption of bilateral relations. In May 1949, the Federal Republic of Germany (FRG) came into being, amputated from its eastern half which remained under Soviet occupation and was shortly to become the German Democratic Republic. A few months later, the civil war in China ended in a victory for the communists and the birth of the People's Republic of China (PRC), allied to the Soviet Union. That the FRG and the PRC belonged to rival political camps in a nascent Cold War scenario added a new kind of obstacle to the revival of pre-war economic cooperation: ideology. To set up normal bilateral relations or even attain mutual recognition was impossible, largely because each country was whole-heartedly bent on integrating into its respective geopolitical bloc.

The FRG and the PRC were totally bound up in their regional priorities (reunification in Bonn's case; national sovereignty for the Beijing regime, as well as the Taiwan issue). This, and their very geographical separation, ruled out any political interest or concern for one another. But whereas politically the most logical conclusion was to accept that official relations were out of the question, it was also true that no direct bones of contention existed; for example, towards the Taiwan nationalist government Bonn abstained from according official recognition, despite pressure from the United States. The political climate worsened markedly in 1950 when China's armed intervention in the Korean War drove the United States to place an even more stringent embargo on her than on the USSR, and to urge the allies to follow suit (Cain 1995, 42). The German government was among the first to come into line: it could hardly do otherwise, since the status of US-controlled occupation continued, and would only officially be lifted in the mid-1950s. Not surprisingly in such a political situation, the initiative for any 
new German overtures devolved on the chief players of the previous phase. Companies and businessmen who had gained experience with China began off their own bat to sound out the new Beijing leaders for signs of readiness to reopen the traditional avenues of exchange, except where prohibitions debarred certain categories of goods and technologies (Stahnke 1972, 139-40). The first Chinese reaction was more encouraging than might have been expected from their often-reiterated solidarity with the socialist bloc. The basic reason for favouring contacts with Germany was the same as in previous decades: what German manufacturers had to offer the Chinese in their bid for modernization was distinctly better quality than the Soviets could provide. There was another motive, which the West Germans detected quite clearly: the new Chinese leaders were keen to diversify their imports, so as to prevent exclusive dependence on Moscow from turning into total economic, political and cultural subordination (Bernardini 2017, 97). Given the understandable lack of official government support, the German economic groups with an interest in trading with the entire socialist galaxy got together and in 1952 organized themselves into an OstAusschuss der Deutschen Wirtschaft (Eastern Committee of German Economy, OADW from now on). The new body undertook to represent the interests of the German economy in advising the government in Bonn; and to promote "useful, effective and increasing relations" with the East, aimed at the conclusion of legally binding agreements with state-owned national economies even in the absence of diplomatic recognition (Jüngerkes 2012, 131; Spaulding 1996, 115). Soon the OADW received endorsement from the Ministry of the Economy as "the sole representative of the German economy in trade with the East." China now belonged to that area, given her apparent progression towards full-scale sovietisation. A special Working Group for China was set up within the OADW, representing all the main firms that had done business there in previous decades (including Siemens, Bayer, BASF, Otto Wolf, AEG and the Deutsche Bank). The OADW's goal was not just to build up the turnover with China, but to work for cultural renewal lest the country slavishly imitate a sluggish Soviet model; it also sought to spur a long-term liberal evolution by keeping China in constant contact with the "free world" (Bernardini 2017, 92). In pursuit of these goals the OADW leaders pressed for immediate engagement in direct contact, before the trade restrictions imposed by politics turned into outright "economic warfare". The method chosen was to keep as low a profile as possible and avoid politicizing economic exchanges; to create discreet temporary zones for negotiation in which timing counted for more than venue, and all parties involved were motivated to keep dialogue technical and avoid the limelight of politics proper, involvement of which would clearly prove a handicap. The OADW made clever use of its own status as being private and "non-governmental" enough not to alarm 
the politicians in Washington and Bonn, but at the same time sufficiently "quasigovernmental" to reassure the Chinese that business was serious, and to suggest formal parity with the interlocutors from two state corporations, the China Import and Export Corporation and the Council for the Promotion of International Trade (Stahnke 1972, 140). When it came to negotiating a framework trade agreement between the parties, this occurred, understandably, at places like international trade fairs where technical outweighed political factors, and above all at unusual venues screened from the public gaze, such as the Chinese delegation to East Berlin (which German industrialists could visit without any apparent political impediment), or the Beijing Embassy at Geneva, on neutral territory.

Negotiations soon brought concrete results, which clearly suited both sides. As early as 1953 a draft trade agreement was drawn up on the basis of barter transactions, which meant that a total amount of exchanges was fixed, that both sides should draw up a list of desired import and export goods, and that they would trade accordingly (Ching 2006, 205). Still more important to the German way of thinking was the drafting of an agreed procedure for exchange and payment of goods, as well as rules to standardize them, lack of which had greatly marred previous transactions. When technical agreement was reached, political interference once again set the clock back. The Chinese top brass seemed to be leveraging the positive result as a stepping-stone towards official recognition between the two countries, proposing for example that the two central banks be involved. For its part, the German Federal Republic had reached a delicate moment in the mid-1950s, poised to regain full sovereignty over its foreign policy; it could not afford the slightest symbolic gesture to mar its loyalty to NATO. When the Chinese invited the OADW to send its delegates to Beijing to sign the trade agreement, Bonn put its foot down, since that might well be construed as a step towards official recognition (Jüngerkes 2012, 142). Only by intense lobbying and a guarantee that it had no intention of holding any political brief did the OADW manage to overcome the Adenauer government's opposition. In the end a German economic delegation was given permission to travel to China in September 1957 and sign the accord. At the delegates' own insistence, the trip maintained a low profile. They declined all the Chinese attempts to increase political visibility - including an invitation to attend the 1st October anniversary of the People's Republic - without detriment to negotiations. The commercial treaty was eventually signed on the September 27, 1957, out of the limelight of western media, thanks to the sui generis, non-governmental standing of the German signatories. All in all, the terms and the build-up of negotiations had created a zone of interaction which both the Germans and in the end the Chinese had every interest in protecting from political interference. Clear 
proof of this came one year later when the agreement expired and the Chinese authorities seemed unconcerned about renewing it. Worrying though the Germans found this, bilateral trade actually suffered no ill effects, but went on in the following years under the rules and procedures established by the original agreement. Evidently these had proved satisfactory to the Chinese counterparts although the official recognition between the FRG and the PRC took place only in October 1972, as a consequence of the changing international conditions

\section{Conclusion}

Although the importance of the 1957 treaty should not be overstated, it does stand out in the history of relations between the German and Chinese areas for at least two reasons. The first is that it connected ipso facto to past relations that had produced important and lasting results at a time when the purely economic angle outweighed considerations of territory and empire, and more generally it bypassed political interference: at the time the German industrialists begged their government not to jeopardise continuation of "ninety years of successful business with China" (Bernardini 2017, 100). The success of the negotiations bore them out, even though the world and the two countries had changed drastically since the pioneering days of the late 19th century. The second is that the agreement paved the way for a policy that not only made the FRG the PRC's first economic partner outside the Soviet bloc in the following decade, but continued to give German economic and technological power top place in the new China's cultural panorama, as it had enjoyed with the previous regime (Stahnke 1972, 148). Without presuming to carry this summary analysis down to our present day, it is fair to consider how much the present situation owes to that model of contact and negotiation, since Germany is still one of the CPR's chief commercial partners, playing an important cultural role in the country by virtue of her quality exports and investments (high technology and innovation), even though her political leverage over the Asian giant has remained extremely limited.

\section{Bibliography}

Berghahn, Volker R. "German Big Business and the Quest for a European Economic Empire in the Twentieth Century." In Quest for Economic Empire. European Strategies of German Big Business in the Twentieth Century, edited by Volker R. Berghahn, 1-34. New York: Berghahn Books, 1996. 
G. Bernardini. "Principled Pragmatism: The Eastern Committee of German Economy and West German-Chinese relations during the early Cold War, 1949-1958." Modern Asian Studies, 51 no. 1 (2017), 78-106.

Cain, Frank. "The US-Led Trade Embargo on China: the Origins of CHINCOM, 1947-52." The Journal of Strategic Studies 18, no. 4 (1995): 33-54.

Ching, Chung-cham. Trade without Flag. West Germany and China 1949-1972. PhD dissertation (unpublished), The University of Hong Kong Pokfulam, 2006.

Feuerwerker, Albert. "The foreign presence in China." In The Cambridge History of China, vol. 12, Part 1, edited by John K. Fairbank, 128-207. Cambridge: Cambridge University Press, 1983.

Giffard, Hermione. "Transculturalism and Translation: New Approaches to Cultural Contact Zones." International Journal for History, Culture and Modernity 4, no. 1 (2016): 29-41. http://doi.org/10.18352/hcm.501

Guiso, Luigi, Paola Sapienza and Luigi Zingales. Cultural Biases in Economic Exchange. NBER Working Paper Series no. 11005, 2004.

H.P. Hahn. "Introduction. Markets as Places: Actors, Structures and Ideologies." in Market as Place and Space of Economic Exchange: Perspectives from Archaeology and Anthropology, edited by Hans Peter Hahn and Geraldine Schmitz, 1-19. Oxford: Oxbow Books, 2018.

Hong, Liu. "Sino-Southeast Asian Studies: Towards an Alternative Paradigm." Asian Studies Review 25, no. 3 (2001): 259-84. https://doi.org/10.1080/10357820108713310

Jüngerkes, Sven. Diplomaten der Wirtschaft. Die Geschichte des Ost-Ausschusses der Deutschen Wirtschaft. Osnabrück: Fibre, 2012.

Kirby, William C. Germany and Republican China. Stanford: Stanford University Press, 1984.

Kirby, William C. "The Internationalization of China: Foreign Relations at Home and Abroad in the Republican Era." The China Quarterly 150 (1997): 433-58.

Kónya, Istvàn. “Modeling Cultural Barriers in International Trade.” Review of International Economics 14, no. 3 (2006): 494-507. https://doi.org/10.1111/j.1467-9396.2006.00626.x

Larrier, Renée. “Empire's Intimacies: The Quotidien in [Post]colonial Contact Zones.” L’Esprit Créateur 44, no. 1 (2004): 96-107. https://doi.org/10.1353/esp.2010.0357

Leitz, Christian. Nazi Foreign Policy, 1933-1941: The Road to Global War. London: Routledge, 2004.

Leutner, Mechthild and Klaus Mühlhahn. "Interkulturelle Handlungsmuster: Deutsche Wirtschaft und Mission in China in der Spätphase des Imperialismus." In Deutschchinesische Beziehungen im 19. Jahrhundert. Mission und Wirtschaft in interkultureller Perspektive, edited by Mechthild Leutner and Klaus Mühlhahn, 9-42. Münster: LIT, 2001.

Machetzki, Rüdiger. "Deutsch-chinesische Wirtschaftsbeziehungen der Gegenwart." In Deutsch-chinesische Beziehungen vom 19. Jahrhundert bis zur Gegenwart, edited by Kuo Heng-yü and Mechthild Leutner. München: K.G. Saur Verlag, 1991.

Marinelli, Maurizio. "Making concessions in Tianjin: heterotopia and Italian colonialism in mainland China." Urban History 36, no. 3 (2009): 399-425. https://doi-org.ezproxy.eui. eu/10.1017/S0963926809990150

Martin, Bernd (ed.). Die Deutsche Beraterschaft in China 1927-1938: Militär, Wirtschaft, Außenpolitik. Düsseldorf: Droste, 1981.

Minc, Leah D. "Monitoring regional market systems in prehistory: Models, methods, and metrics." Journal of Anthropological Archaeology 25, no. 2 (2006): 82-116. https://doi.org/10.1016/j.jaa.2005.09.003 
Nield, Robert. China's Foreign Places. The Foreign Presence in China in the Treaty Port Era, 1840-1943. Hong Kong: Hong Kong University Press, 2015.

Osterhammel, Jürgen. "Semi-Colonialism and Informal Empire in Twentieth-Century China: Towards a Framework of Analysis." In Imperialism and After. Continuities and Discontinuities, edited by Wolfgang J. Mommsen and Jürgen Osterhammel, 290-314. New York: Harper Collins Publisher, 1986

Raj, Kapil. "The historical anatomy of a contact zone: Calcutta in the eighteenth century." The Indian Economic and Social History Review 48, no. 1 (2011): 55-82. https://doi.org/10.1177/001946461004800103

Spillman, Lyn. "Enriching Exchange. Cultural Dimensions of Markets.” The American Journal of Economics and Sociology 58, no. 4 (2006): 1047-71. https://doi.org/10.1111/j.15367150.1999.tb03407.x

Stahnke, Arthur A. “The Political Context of Sino-West German Trade.” In China's Trade with the West. A Political and Economic Analysis, edited by Arthur A. Stahnke, 135-173. New York: Praeger, 1972.

Tanner, Harold M. China: A History. Vol. II: From the Great Qing Empire Through the People's Republic of China. Indianapolis: Hackett Publishing, 2010. 